Research.

\title{
The effect of perceived usefulness, perceived ease of use, and complexity upon the acceptance of computerized audit technique (ACAT) at the Finance and Development Supervisory Agency (FDSA) Republic of Indonesia
}

\author{
Blasius Fembriyanto Trisno Saputro ${ }^{{ }^{*}}$, Gideon Oki Manalu ${ }^{2}$ \\ $1^{1 *}$ Department of Accounting, Polytechnic of Bina Budaya Cipta (BBC), Sukabumi, Indonesia \\ ${ }^{2}$ Mercu Buana University, Jakarta, Indonesia \\ fembrixs@gmail.com (B.F. T. Saputro)manaluoki@gmail.com (G. O. Manalu) \\ * Corresponding author \\ Received: February 15, 2019; Accepted: April 27, 2019; Published: June 30, 2019.
}

To cite this article: Saputro, Blasius Fembriyanto Trisno and Gideon Oki Manalu. (2019). The effect of perceived usefulness, perceived ease of use, and complexity upon the acceptance of computerized audit tehnique (ACAT) at the Finance and Development Supervisory Agency (FDSA) Republic of Indonesia. The Accounting Journal of BINANIAGA. 4 (1): 15-26. doi:

\begin{abstract}
Perceived Usefulness (PU) in matters relation of the dimensions of enhanced performance and productivity will make the auditors use the Acceptance of computerized audit technique (ACAT). Perceived Ease of Use (PEOU), through their knowledge, ease of operation, and the need for the work that is free from businesses that facilitate the use of information systems being used will make the auditors Acceptance of ACAT. Complexity is a hassle on infrastructure and the required time factor affecting the use of Acceptance of ACAT. Results of this study are carried out through the delivery of questionnaires to the auditor at the Finance and Development Supervisory Agency (FDSA), confirm that there is significant Perceived Usefulness (PU) and Perceived Ease of Use (PEOU) against Acceptance of ACAT and Complexity makes the auditors didn't Acceptance of ACAT.
\end{abstract}

Keywords: Perceived Usefulness, Perceived Ease of Use, Complexity, Acceptance of ACAT

\section{Introduction}

\section{Research Background}

The development of the Information Technology thru Computerized Audit Technique (ACAT) in auditing has been an important role at the Finance and Development Supervisory Agency (FDSA).

In order FDSA enables to execute the tasks of controlling better in quality, it requires a proper technology to do its tasks. FDSA RI is a government institution Non Department which is having the role to control the finance and the development in Indonesia. It is one of the internal government controlling institutions having an important role which has been appointed to execute the financial and development control in Indonesia. Due to the aforementioned tasks, responsibilities and authorities, FDSA RI is obliged to apply the information technology to support its productivity and performance to be more effective and efficient.

Blasius Fembriyanto Trisno Saputro and Gideon Oki Manalu. The effect of perceived usefulness, perceived ease of use, and Complexity upon the acceptance of computerized audit tehnique (ACAT) at the Finance and Development Supervisory Agency (FDSA)

Republic of Indonesia 
Executing its tasks, FDSA needs the computer with an applicable technology to support the tasks of FDSA auditors to process the data received from the entities audited. Due to the development of the information technology, FDSA is obliged to execute its controlling to be better in quality using such the technology.

According to the Indonesian Accountant Association (IAI) (2011), executing an auditing, the auditor has to evaluate various big alternative information to meet the standard of the job requirement at place which is a sufficient proof of competent audit that has been getting thru the inspection, supervision, recommendation, and confirmation as the fundamental declaration that such the financial report is acceptable.

Based on the result of the survey, it is declared that the auditors should have applied ACAT obviously. By having the supporting program or computer assisted audit techniques (CAAT), it will help the auditors executing the audit procedures to be more efficient and effective and to make the auditing easier.

The implementation of Computerized Audit Technique (ACAT) has provided better result and has made the auditing process more rapid. Nevertheless, the application of ACAT is expected to be able to improve the performance of FDSA RI auditors in auditing which is it is more effective and efficient.

Referred to the opinion of Nani Norilin (2009), ACAT is the instrument to check the financial report using computer technology. Using ACAT is very important for the auditors because more companies have been applying the computer to record and to process their business transactions, nevertheless, ACAT is able to improve the efficacy and efficiency of the auditors doing the audit procedure accordingly.

Model of the acceptance of technology was developed by David et al (1989) based on TRA model. TRA model is applicable due to the decision made by the individual to accept a technology of information system is explainable and predictable. TAM model was developed by Fred D. Davis (1989) is a model being used more often in the TI research since this model is simple and easy to be applied. (in the article of Ratih Wijayanti, 2009)

In general, the research about the acceptance of the information technology is based on the Technology Acceptance Model (TAM) describing that an individual acceptance upon the computer technology is based on two kind of beliefs; a). Perceived Usefulness (PU) which is the extent to which a person believes that using a certain system will improve his job performance; b) Perceived Ease of Use (PEOU) which is the extent to which a person believes that using a certain technology will only need a little effort (Davis, 1989)

TAM has added two main constructions into TRA model. Those two constructions are perceived usefulness and perceived ease of use. TAM has argued that the individual acceptance upon the system of information technology is due to those two constructions.

Both Perceived Usefulness and Perceived Ease of Use have influenced the acceptance of IT. Users of the technology will accept to use the technology (acceptance of IT) if they realize that such the technology system is usefull and easy to be used. Suppose someone has realized that the system is easy to operate and has given him or her a benefit to improve his/her performance and the information technology has made him/her easy to perform his tasks and responsibilities.

This research has applied the Technology Acceptance Model (TAM) by using 3 main constructs; user perception upon the ease of using ACAT (perceived ease of use); user perception upon ACAT usefullness (perceived usefulness) and user acceptance upon the Computerized Audit Technique (ACAT). The writer has included the additional variable adapted from the research done by Igbaria et

Blasius Fembriyanto Trisno Saputro and Gideon Oki Manalu. The effect of perceived usefulness, perceived ease of use, and Complexity upon the acceptance of computerized audit tehnique (ACAT) at the Finance and Development Supervisory Agency (FDSA) 
al.(1995) which is the complexity. The writer will study such the complexity related to the difficulties of computer technology used by the auditor as the user at work.

\section{Framework of Research Problem}

Referred to the background stated above, the scope limitation is required to ease the description so that the problems researched are getting along with, nevertheless the researcher has identified the following problems;

a. Will Perceived Usefulness (PU) affect the acceptance of Computerized Audit Technique (ACAT)

b. Will Perceived Ease of Use (PEOU) affect the acceptance of Computerized Audit Technique?

c. Will Complexity (COMPL) affect the acceptance of Computerized Audit Technique?

\section{Aims and Contribution of the Research.}

\section{a. Aims of the Research}

1) Examining the effect of Perceived Usefulness (PU) upon the acceptance of Computerized Audit Technique.

2) Examining Perceived Ease of Use (PEOU) upon the acceptance of Computerized Audit Technique.

3) Examining the effect of Complexity (COMPL) upon the acceptance of Computerized Audit Technique (ACAT)

\section{b. Research Contribution.}

Result of this research is expected to contribute :

1) Theory Contribution:

This research is expected to be an input for the science particularly in accountancy which is related to the Accountancy Information System (SIA), computerized auditing, and behavioral aspect due to the application of information technology as well as the study of theories application and other literatures which are in accordance with the actual facts of the companies.

\section{2) Practical Contribution:}

a) The development of organization especially The Office of the Finance and Development Supervisory Agency (FDSA) R.I refers to the effort how to improve its job performance which is accepted by the organization, using one of the model is to predict and to explain the acceptance and using computerized audit technique which is Technology Acceptance Model (TAM)

b) Educational world, particularly as the guideline for the next researchers who are going to study the similar scope of the problem such as individual attitude upon the acceptance and application of new technology.

\section{Research Metodology}

\section{Type of the Research}

Type of this research is casually indicating the distribution of correlation between independent variables and dependent variable refers The Effect of Perceived usefulness, Perceived Ease of Use, and Complexity upon the Acceptance of Computerized Audit Technique (ACAT).

Blasius Fembriyanto Trisno Saputro and Gideon Oki Manalu. The effect of perceived usefulness, perceived ease of use, and Complexity upon the acceptance of computerized audit tehnique (ACAT) at the Finance and Development Supervisory Agency (FDSA) 


\section{Definition and Operational Variable.}

\section{a. Perceived Usefulness}

Perceived usefulness as variable $\mathrm{X} 1$ is defined as the extent to which a person believes that using a technology will improve her or his performance. Based on the definition above, it explains that perceived usefulness is such a belief about the process of decision making. Therefore, when a person believes that the information system is useful, he or she will surely use it. But, when a person does not believe that the information system is not useful, he or she will never use it. (Jogiyanto 2008: 114).

\section{b. Perceived Ease of Use}

Perceived ease of use as the variable of $\mathrm{X} 2$ is defined as the extent to which a person believes that using a technology will be free of effort. Refers to the definition above, it explains that the construct of perceived ease of use is a belief about the process of decision making. When a person believes that such an information system is easy to use, he or she will surely use it. But, when a person believes that such an information system is difficult to use, he or she will never use it. (Jogiyanto, 2008:115).

\section{c. Complexity}

Complexity as Variable $\mathrm{X} 3$ is defined as the extent to which the difficulty of computer technology is easy to be understood and applied by the user Davis (1989) and Igbaria et al. (1996) have measured the complexity of time consumed to execute the tasks, to integrate the computer result with the jobs being done. (Jogiyanto, 2008: 117).

\section{d. The Acceptance of Compterized Audit Technique (ACAT)}

ACAT is defined as the instrument and technology being used to examine either directly or indirectly the internal logic of a computer application to process the data. Perceived ACAT is a kind of acceptance to use the information technology as the supporting tool in auditing. Suryana (2013).

ACAT is the tool how to examine the financial report using computer technology. Using ACAT has been the most important requirement for an auditor, since many companies have been using computer to record and to process their business transaction. However, ACAT can improve the auditors' efficiency and effectiveness to execute audit procedure. (Nani Novrilin, 2009).

\section{Measuring the Variables}

The instrument which has been used to measure the variable is Likert Scale, it has 5 levels of answering method; absolutely disagree, disagree, a little bit disagree, agree, absolutely agree.

\section{Population and Sample}

The population of this research is covering the Area of the Finance and Development Supervisory Agency (FDSA) consisting of 150 persons. The population has been dedicated only for the auditors, qualified auditors, supervisory auditors, primary auditors, young auditors and medium auditors using the technique of census sampling which is all the population as the sample.

Blasius Fembriyanto Trisno Saputro and Gideon Oki Manalu. The effect of perceived usefulness, perceived ease of use, and Complexity upon the acceptance of computerized audit tehnique (ACAT) at the Finance and Development Supervisory Agency (FDSA) 


\section{Analysis Method}

\section{a. Descriptive Analysis of the research variables}

Data collected of this research are tabulated according to the requirement of analysis that will be done. There are 3 exogen variables, Perceived Usefulness, Perceive Ease of Use and Complexity. Endogen variable is Computerized Audit Technique (ACAT). Result of SPSS of the descriptive of research variable will be analyzed to see the range of theory and its actual refers to its deviation.

\section{b. Test of Data Quality}

Data collection that will be used in this research have to get thru the validity test, reliability test, and normality test. The aims of the test above is to recognize the availability of the related data which could be used for further research. (Renyowijoyo, 2005).

\section{c. Classical Assumption Test}

Executing a multiple regression analysis, classical assumption test has to be done due to the requirement of analysis to ensure the data are beneficial and useful. Classical assumption test has covered normality test, multicolinearity test and heteroscedasticity test.

1) Normality Test Data

Data of normality test can be done by using 3 methods; KolmogorofSmirnov (K-S test), histogram graph and P-Plot scattering curve.

2) Multicolinearity Test

Is to test whether the regression model has found out the correlation among the independent variables.

3) Heteroscedasticity Test

Is to test whether the regression model has found out the variance differences between one residual observation to another one is fixed or homoscedasticity.

4) Descriptive Statistics Test.

Descriptive statistics has provided the criteria data descriptions of means value, standard deviation, variant, maximum, minimum, sum, range, curtosis, and scewness.

5) Multiple Regression Test.

Using the following equation:

$\mathrm{Y}=\mathrm{\alpha}+\mathrm{Bx}+\mathrm{e}$

$Y=$ Acceptance of Computerized Audit Technique (ACAT).

$b=b 1, b 2, b 3=$ Coefficient of regression distribution / parameter value

$\mathrm{X}=$ Perception usefulness (Perceived Usefulness) / Perceived Ease of Use) / Complexity.

$A=$ constant (intersept).

$\mathrm{E}=$ residual or prediction error.

\section{Hypothesis Test}

\section{a. Hypothesis test of correlation coefficient with $\mathbf{t}$ test.}

Testing each variable of Perceived Usefulness, Perceived Ease of Use, and Complexity against the Acceptance of Computerized Audit Technique (ACAT).

Blasius Fembriyanto Trisno Saputro and Gideon Oki Manalu. The effect of perceived usefulness, perceived ease of use, and Complexity upon the acceptance of computerized audit tehnique (ACAT) at the Finance and Development Supervisory Agency (FDSA) 


\section{b. Determinant Coefficient $\left(\mathbf{R}^{2}\right)$.}

Indicating the percentage of the varied independent variables that could be explained by the regression equation obtained. Determinant Coefficient $\left(R^{2}\right)$ is an exact measurement or suitable regression distribution obtained from the prediction result against the data result of the research.

\section{Result and Description}

1. The Effect of the dimensions of Perceived Usefulness (X1), Perceived Ease of Use (X2), Complexity (X3) upon the Acceptance of ACAT Auditor (Y)

\section{a. Regression Coefficient}

Regression coefficient of the effect of the dimension of Perceived Usefulness (X1), Perceived Ease of Use (X2), Complexity (X3) upon the Acceptance of ACAT (Y) is described in the following table.

Table 1 Regression coefficient of Dimensions X1, X2, X3 upon Y.

Coefficients $^{\mathrm{a}}$

\begin{tabular}{|c|c|c|c|c|c|c|}
\hline \multirow{2}{*}{\multicolumn{2}{|c|}{ Model }} & \multicolumn{2}{|c|}{$\begin{array}{c}\text { Unstandardized } \\
\text { Coefficients }\end{array}$} & \multirow{2}{*}{$\begin{array}{c}\begin{array}{c}\text { Standardi } \\
\text { zed } \\
\text { Coefficie } \\
\text { nts }\end{array} \\
\text { Beta }\end{array}$} & \multirow[t]{2}{*}{$\mathrm{t}$} & \multirow[t]{2}{*}{ Sig. } \\
\hline & & B & Std. Error & & & \\
\hline \multirow[t]{8}{*}{1} & (Constant) & 35,148 & 5,508 & & 3,640 & ,000 \\
\hline & $\begin{array}{l}\text { Performance } \\
\text { Improvement dimension }\end{array}$ & ,752 & , 172 & ,358 & 5,876 & ,000 \\
\hline & Productivity dimension & ,383 & ,142 &, 353 & 4,248 & ,001 \\
\hline & Knowledge dimension &, 812 & ,154 & ,462 & 4,248 &, 000 \\
\hline & Operation dimension & ,821 & 251 & ,231 & 3,160 &, 002 \\
\hline & Effort / work dimension & 627 & ,135 & ,314 & 2,817 &, 003 \\
\hline & Time dimension &,- 352 & , 165 &,- 218 & $-1,775$ &, 053 \\
\hline & $\begin{array}{l}\text { Infrastructure and Facility } \\
\text { dimension }\end{array}$ &,- 347 & , 158 &,- 215 & $-1,851$ & ,051 \\
\hline
\end{tabular}

Resource: enclosure of each dimension of the Research Variable

The calculation of multiple regression analysis on the variable data of Acceptance of ACAT upon the Perceived Usefulness, the Perceived Ease of Use, the Complexity has gained the regression $\mathrm{bX}_{1.1}$ which is the Performance Improvement dimension of 0.752 and regression $\mathrm{bX}_{1 / 2}$ which is the Productivity dimension of 0.383 , regression $b_{21}$ which is the Knowledge dimension of 0.812 , and regression $\mathrm{bX}_{22}$ which is the Operation dimension of 0.821 , and regression $b_{23}$ which is the effort/work dimension of 0.627 , regression $b X_{3.1}$ which is Time dimension of -0.352 and regression $b X_{3.2}$ which is the Infrastructure and Facility dimension of -0.347 and constant / intersept $\alpha$ of 35.148. Therefore, the correlation dimension between independent variables and dependent variable could be described by the following multiple regression equation:

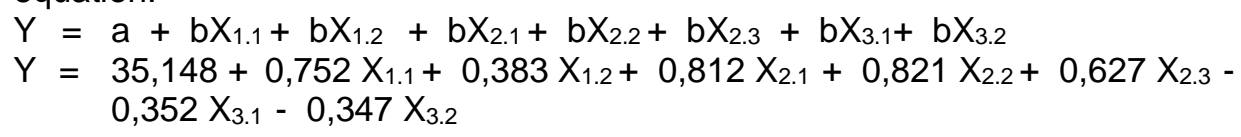

Blasius Fembriyanto Trisno Saputro and Gideon Oki Manalu. The effect of perceived usefulness, perceived ease of use, and Complexity upon the acceptance of computerized audit tehnique (ACAT) at the Finance and Development Supervisory Agency (FDSA) 
Result of Multiple Linear Regression Test.

1) Coefficient constanta is 35.148 describing that the dimensions of variables Perceived Usefulness, Perceived Ease of Use, Complexity are constant at 0 (nul), and $Y$ is 35.148 .

2) Regression coefficient of the dimensions of independent variables of the research has explained that a positive effect of the variables of Perceived Usefulness and Perceived Ease of Use upon the ACAT has happened and a negative effect of the Complexity variable upon the ACAT has happened. The regression coefficient value of Perceived Ease of Use will be meaningful if the related dimension is increased 1 unit, then the value of ACAT (Y) will be increased according to each regression coefficient obviously. The independent variable of Complexity has proven that a negative effect of its dimension upon the ACAT has occured.The regression coefficient value of the Complexity dimension will be meaningful if the dimension of Complexity variable is increased 1 unit, and the value of ACAT $(Y)$ will be decreased, it explains that the existence of Complexity will decrease the acceptance decision of ACAT or tends to reject to use the ACAT.

\section{b. Correlation Coefficient}

The strong effect of the dimension of Perceived Usefulness $\left(X_{1}\right)$ which consists of Performance Improvement dimension and Productivity dimension upon the Acceptance of ACAT $(Y)$ is indicated by its correlation coefficient. The result of the calculation has gained $R=0.527$ as mentioned on the following table.

Table 2. Correlation Coefficient value of $\mathrm{X} 1, \mathrm{X} 2, \mathrm{X} 3$ upon $\mathrm{Y}$

\begin{tabular}{|c|r|r|r|}
\hline$R$ & $R$ Square & \multicolumn{1}{|c|}{$\begin{array}{c}\text { Adjusted } R \\
\text { Square }\end{array}$} & $\begin{array}{c}\text { Std. Error of the } \\
\text { Estimate }\end{array}$ \\
\hline, $583^{\mathrm{a}}$ &, 339 &, 228 & 4,26321 \\
\hline
\end{tabular}

Source: Enclosures of Research Variable per each dimensions

However, the guideline of the interpretation about the correlation coefficient referred to Sugiyono's opinion as follows:

Table 3: Interpretation Guideline

\begin{tabular}{|c|c|}
\hline $\begin{array}{c}\text { Coefficient } \\
\text { Interval }\end{array}$ & Degree of Correlation \\
\hline $0,00-0,199$ & The weakest \\
\hline $0,20-0,399$ & Weak \\
\hline $0,40-0,599$ & Quite strong \\
\hline $0.60-0,799$ & Strong \\
\hline $0,80-1,000$ & The strongest \\
\hline
\end{tabular}

Source : Sugiyono (2007)

Based on the interpretation guideline on the table above, it has explained that the effect of the dimensions of Perceived Usefulness, Perceived Ease of Use and Complexity upon the Acceptance of ACAT is quite strong. Therefore, it can be defined that a sufficient strong effect of the dimensions of Perceived Usefulness, Perceived Ease of Use, Complexity upon the Acceptance of ACAT has happened.

Blasius Fembriyanto Trisno Saputro and Gideon Oki Manalu. The effect of perceived usefulness, perceived ease of use, and Complexity upon the acceptance of computerized audit tehnique (ACAT) at the Finance and Development Supervisory Agency (FDSA)

Republic of Indonesia 


\section{c. Determinant Coefficient}

Determinant coefficient is quadratic correlation coefficient $\left(R^{2}\right)$ between the dimension of variables $\mathrm{X} 1, \mathrm{X} 2, \mathrm{X} 3$ and $\mathrm{Y}$ variable which is 0.339 indicating that the dimensions of Perceived Usefulness, Perceived Ease of Use, Complexity have contributed $33.9 \%$ for the Acceptance of ACAT.

\section{d. Significance Test}

Furthermore, t-text analysis has to be done. The Analysis result has gained t-count as mentioned on table 1 above indicating that the dimension of Perceived Usefulness which consits of Performance Improvement dimension and Productivity one has obtained t-count of 5.876 and 4.248 which are bigger than t-table $(n=150 ; \alpha=0.05)=1.960$ and $t$-sign $0.000<0.05$, the variable of Perceived Ease of Use has gained the value of of $t$-count of Knowledge dimension of 4.284, Operational one of 3.160 and effort/work one of 2.817, and Complexity variable that consists of the Time dimension required has obtained $\mathrm{t}$-count of -1.775 , and Infrastructure and Facility dimension has obtained t-count ot -1.851 which is lower than $t$-table $(n=150 ; \alpha=0.05)=1.960$ but each $t$-sign value of 0.053 and $0.051>0.05$. Nevertheless, it can be said that there is not any significant effect of Complexity upon the increasing of Acceptance of ACAT happened.

\section{Description}

a. There is a positive and significant effect of Perceived Usefulness upon the Acceptance of ACAT Auditor happened.

Perceived Usefulness is defined to what extent a person believes that using the information system can improve his job performance. The definition above has explained that Perceived Usefulness is a belief about the process of decision making. If a person believes that the system is useful, he or she will use it, but if a person believes that the information system is not useful then he or she will never use it. This kind of concept has described that the usefulness of the system for the user is related to the productivity, job performance or effectiveness, importance to job, and overall usefulness.

b. A positive and significant effect of Perceived Ease of Use upon the Acceptance of ACAT Auditor has happened.

Perceived Ease of Use (PEOU) is a perception about using the thing easily which is to what extent a person believes that using a certain system does not need much effort. Though, each person has varied effort to spend, but in general usually in order to avoid any rejection of using the system, it must be user friendly which is free of effort.

The concept of perceived ease of use has indicated the extent to which a person believes that using the information system is easy to operate and free of effort. This concept has covered a clear description how to use the information system easily, so that it is meeting the user's expectation.

Therefore, the auditors at the Finance and Development Supervisory Agency (FDSA) R.I. would have accepted to use the system since it is easy to operate.

c. There is a Negative Effect of Complexity upon the Acceptance of ACAT Auditor.

Complexity is people perception about computer technology which is it is difficult to be understood and to be operated. The more complex a technology is innovated, the less people use it.

Blasius Fembriyanto Trisno Saputro and Gideon Oki Manalu. The effect of perceived usefulness, perceived ease of use, and Complexity upon the acceptance of computerized audit tehnique (ACAT) at the Finance and Development Supervisory Agency (FDSA) 
Complexity of a technology has affected the auditors at FDSA RI using it. The technology system owned by FDSA RI has made the auditors difficult to do their tasks and responsibility. The more complexity of the technology system has caused the auditors difficult to accept it. Because the auditors need quite the time to finish their job. A sophisticated development and innovation of the technology has made the auditors facing the problem to operate it and they are not in the position to accept such a technology. However, nowadays the expertise of auditors has not been able to get along with such a modern technology yet. Nevertheless, this research can be an input for the auditors to improve their expertise particularly related to the technology development which is it could be done by following the training and development for the auditors.

\section{Conclusion, Implication and Suggestion}

\section{Conclusion}

There is a positive effect of Perceived Usefulness and Perceived Ease of Use happened upon the Acceptance of ACAT auditors at the Finance and Development Supervisory Agency (FDSA) R.I. There is a negative effect of Complexity happened upon the Acceptance of ACAT, it means that the existence of complexity has decreased the auditors' Acceptance of ACAT at FDSA R.I.

\section{The Research Limitation}

This research is only able to be used as an analysis for a limited research objects which is the professional auditors at the Finance and Development Supervisory Agency (FDSA) Republic of Indonesia which have depicted the expertise of the auditors refers to the acceptance of ACAT zone only. However, it cannot generalize all the auditors in Indonesia.

This research has had the limitation of time to perform the field survey. It is quite difficult to get back the questionnaires which already distributed to the auditors as the respondents. It has happened due to they have big responsibilities and tasks to be performed and they do not have enough time to answer the questions offered.

\section{Suggestions}

It is suggested that further research can add some factors affecting the auditor recruitment and enlarge the area to be researched if possible. Besides that, the researcher has suggested the FDSA RI to improve the skills and ability of the auditors to be able to accept easily the technology supporting their tasks and responsibilities. Having the education and training particularly related to the technology development with modern work facilities can give the auditors a certain skill which can reduce the problems and tasks complexity at work. Training and education session will make the auditors having more knowledge and skills, so that they can accept the technology that can support and make their task easily and rapidly.

Further research can be done by other researchers related to the Acceptance of ACAT refers to the auditors more properly by adding the study about other factors that could make auditors at FDSA RI accept the ACAT accordingly and properly.

\section{Implication}

a. Technology acceptance or Acceptance of ACAT can be an evaluation of the implementation of the information technology system at the office of the Institution Finance and Development Control (FDSA) Republic Indonesia, however, there are still some improvement to be done related to the

Blasius Fembriyanto Trisno Saputro and Gideon Oki Manalu. The effect of perceived usefulness, perceived ease of use, and Complexity upon the acceptance of computerized audit tehnique (ACAT) at the Finance and Development Supervisory Agency (FDSA) 
implementation of the information technology system due to the human resources quality regarding how to use the information technology system. Therefore, the management of FDSA RI should have provided some programs to improve the people who are using the information technology system thru the training session to evolve the auditors' job performance. Finally an increasing of the acceptance of information technology system will happen.

b. Perceived Usefulness is required for the auditor who believes that technology application will be as an auditing process. It is such the technology system can improve the auditors' job performance and productivity accordingly.

c. The improvement of Perceived Ease of Use for the auditors is required, because by improving the knowledge and skills of the auditors about such the technology system, it could help them to do their job more properly. Nevertheless, the auditors will trust and decide to use it.

d. Complexity is a big problem for the auditors to do their job. So that auditors need to manage their time schedule and to use the facilities and infrastructures that can help them finish their tasks properly. Therefore the difficulties of tasks can be minimized or even eliminated.

\section{References}

Davis, F. D. (1989). Perceived Usefulness, Perceived Ease of Use, and User Acceptance of Information Technology. MIS Quarterly, 13: 319-340.

Davis, F.D, Bagozzi. R.P. \& Warshaw. P.R. (1989). User Acceptance of Computer Technology: A Comparison of Two Theoretical Models, Management Science, 35: 982-1003.

Gardner, C. Amoroso, D (2004), Development of an Instrument To Measure The Aceptance Of Internet Technology By Consumers. Conference on System Sciences. USA: Procedings of the $37^{\text {th }}$ Hawai Internasional.

Jogiyanto. (2008). Sistem Informasi Keperilakuan, Yogyakarta: Andi Publisher.

Ikatan Akuntan Indonesia. (2011). Standar Profesional Akuntan Publik (SPAP) Jakarta : Salemba Empat.

Kawedar, S. H., Warsito. (2004). Pengaruh Komputer Mikro terhadap Kinerja dan Kepuasan Auditor. Tesis. Tidak Dipublikasikan. Jakarta: Institut Keuangan Perbankan dan Informatika Asia

Novrilin, N. (2009). Pelaksanaan TABK dalam Pengujian Audit Untuk Menentukan Baik Kewajaran Akun Penjualan maupun Akun Piutang Dagang. Jurnal Akuntansi.

Noviari, N. (2009) Pengaruh Kemajuan Teknologi Informasi Terhadap Perkembangan Akuntansi. Jurnal Teknologi Inforrmasi.

Suseno, B.H. (2009). Analisis Faktor-Faktor Yang MempengaruhiPenerimaan Oleh Karyawan PT.KAI (Persero) Terhadap Sistem E-ticket di Semarang: Dengan Menggunakan Pendekatan Technology Acceptance Model (TAM). Tesis. Semarang: Universitas Diponegoro

Suryana, W. (2013). Sistem Informasi Dalam AkademikUniversitas Islam Negeri Sunan Kalijaga Yogyakarta Berbasis Komputer. Karya Tulis. Program Studi Teknik Informatika, Fakultas Sain dan Teknologi, Yogyakarta: UIN Sunan Kalijaga

Blasius Fembriyanto Trisno Saputro and Gideon Oki Manalu. The effect of perceived usefulness, perceived ease of use, and Complexity upon the acceptance of computerized audit tehnique (ACAT) at the Finance and Development Supervisory Agency (FDSA) 
Tangke, N. (2004). Analisa Penerimaan Penerapan Teknik Audit Berbantuan Komputer (TABK) Dengan Menggunakan Technology Acceptance Model (TAM) Pada Badan Pemeriksa Keuangan (BPK) RI. Jurnal Akuntansi dan Keuangan, 6 (1).

Thompson, R. L., Higgins, C.A., Howwel, J.M. (1994). Influence of Experience on Personal Computer Utilization: Testing a Conceptual Model. Journal of Management Information Systems. 21 (42): 132-451.

Wijayanti, R. (2009). Analisis Technology Acceptance Model (TAM) Terhadap FaktorFaktor yang Mempengaruhi Penerimaan Nasabah Terhadap Layanan Internet Banking (Studi Empiris Terhadap Nasabah Bank di Depok). Tesis. Jurusan Akuntansi, Fakultas Ekonomi. Jakarta: Universitas 
The Accounting Journal of BINANIAGA Vol. 04, No. 01, June 2019 p-ISSN: $2527-4309$, e-ISSN: $2580-1481$

$5^{\text {th }}$ Accreditation Rating: January 14, 2019 - January 13, 2024

This page intentionally be emptied.

Blasius Fembriyanto Trisno Saputro and Gideon Oki Manalu. The effect of perceived usefulness, perceived ease of use, and Complexity upon the acceptance of computerized audit tehnique (ACAT) at the Finance and Development Supervisory Agency (FDSA) 